\title{
FACTORS INFLUENCING THE DEMAND FOR DOMESTIC SERVANTS IN OYO STATE, NIGERIA
}

\author{
Oludayo Tade and Adeyinka A. Aderinto
}

\begin{abstract}
The employment of domestic servants is a common phenomenon in Nigeria, where vulnerable children are internally trafficked to work as domestic servants in affluent urban households. While scholars have investigated the push factors aiding the demand for child domestic servants in West Africa, attempts to understand the dynamics underlying the demand are scarce. Hence, this study investigated factors that propel demand for domestic servants in Oyo State. The data were generated using both the quantitative and qualitative methods. The results show three categories of employers: newly married women, married women with grown-up children, and isolated widows and grandparents. The demand is driven by role dualism, workload, and the need for companionship. The incipient decline in the extended family structure of social exchange system (fostering) and preference for "outsiders" rather than family members justify the demand for and use of domestic servants. The study recommended welfare programmes targeted at demanding households and an intervention strategy for the trafficked children.
\end{abstract}

Keywords: trafficking, Oyo State, welfare, family, demand

Oludayo Tade, Ph.D. teaches at the Department of Sociology, University of Ibadan, Ibadan, Oyo State, Nigeria. E-mail address: dotad2003@yahoo.com

Adeyinka A. Aderinto, Ph.D. is Professor of Criminology at the Department of Sociology, University of Ibadan, Ibadan, Oyo State, Nigeria. E-mail address: aderinto@yahoo.com 
The use of adolescents in domestic service is prevalent in urban centres across Africa (Okafor, 2009). The International Labour Organization or ILO (2002) estimates that there are 48 million children in sub-Saharan Africa who are economically active in the 10- to 14-yearold age group, representing $20 \%$ to $30 \%$ of the children, a higher percentage than anywhere else in the world (Adamassie, 2003). The economic work of children often correlates with poverty (Aderinto, 2000; Adamassie, 2003) and poverty is widespread in Africa. According to the Bureau of International Labour Affairs (1998), children in domestic service constitute the most common form of urban child labour in developing countries. These children work in cottage industries, mechanical workshops, and in private homes as domestic servants (Hodges, 2001). Most of these children, including those in domestic service, are victims of trafficking (Okafor, 2009; Tade, 2010).

As a part of the global community, Nigeria is not insulated from the scourge of child trafficking. It is a source, transit, and destination country for women and children trafficked for the purposes of forced labour and commercial sexual exploitation. Within Nigeria, women and girls are trafficked primarily for domestic servitude and commercial sex. Boys are trafficked for forced labour in street vending, agriculture, mining, stone quarries, and domestic service. Religious teachers also traffic boys, called almajiri, for forced begging. Women, girls, and boys are trafficked from Nigeria to other West and Central African countries, primarily Gabon, Cameroon, Ghana, Chad, Benin, Togo, Niger, Burkina Faso, and The Gambia, for the purposes listed above. Benin is a primary source country for boys and girls trafficked for forced labour in Nigeria's granite quarries (United States Department of State, 2009).

The United Nations International Children's Education Fund (UNICEF, 2006) and the International Labour Organisation (2003) estimated that about 15 million children in Nigeria between 10 and 14 years of age were working in the informal economy. Of these working children, $40 \%$ run the risk of being trafficked for forced labour, six million do not attend school, and two million work more than 15 hours per day. This contradicts the prescriptions of the Minimum Age Convention No.138, Convention No.182, and the Worst Forms of Child Labour Convention, which state that children younger than 15 can only be employed in domestic service or home-based work and are not allowed to work for more than 8 hours per day. According to a study conducted by UNICEF (2004), one-third of the trafficked persons end up in forced labour and another third in domestic work. Nigeria, thus, ranks among countries of the world where slavery and involuntary servitude thrive, with children being used as domestic servants and prostitutes (United States Department of State, 1999).

Nigeria’s 2003 Child Rights Act also criminalises child trafficking, although only 20 of the 36 states have enacted it (Tade, 2010). Article 35 of the Child Rights Acts (CRA) focuses on the prevention of child trafficking for any purpose or in any form. It stresses that the trafficking of a child for exploitative purposes, whatever the means used, should be considered a crime. The phenomenon of house-help is highlighted in the Amendment to the National Agency for the Prohibition of Trafficking in Persons (NAPTIP) Act of December 15, 2005. This Amendment specifically provides that no child (persons under the age of 18) should be used in domestic service outside his or her family. The essence of this provision is to fortify the rights of the child as provided in the Child Rights Act and to ensure full mental and physical development of the child. 
The basic presumption of the law is that a child trained within the family environment will be faithfully cared for, while the one outside the family environment may be exposed to abuse, deprivation, and exploitation. Despite these lofty provisions and their ratification by Nigeria, children are still being brought from the rural areas to the urban centres under the pretext of finding job opportunities which are not available in the rural areas. These children, who ordinarily should not be engaged in labour, are brought from rural areas to work as livein domestic servants. In many cases, they are internally trafficked from rural to urban areas (ILO, 2002). Olútáyò (1994) asserts that many people in Nigeria do not consider child labour as a problem because it is widely believed that it is a process of socialisation of the children.

Fostering, which is seen as "a strategy that redistributes the costs and benefits of child bearing” (Isiugo-Abanihe, 1994) is a long-standing tradition across Africa. As Wusu and Isuigo-Abanihe (2003) observe, erstwhile strong family ties have been under considerable stress in the past decade, as various child-fostering practices no longer enjoy general acceptance in the communities and the cost of raising children is becoming the sole responsibility of biological parents. The fading of fostering practices has made financially dependent households and their wards susceptible to traffickers' "tricks"; adolescents are released to be used as domestic servants in urban households (Tade, 2010). More adolescents are procured from deprived rural households by agents driven by economic motives and transported across long distances to work in urban households (Okaba \& Okolie, 2004; Tade, 2010).

The problem is that children in domestic service are marginally addressed in research in Nigeria owing to their obscurity. A UNICEF study claims that children working as domestic servants/labourers have experienced some of the worst cases of abuse (UNICEF, 2006). Although earlier researchers, including Coser (1973), have predicted that domestic service would become a less visible occupation with capitalist penetration, domestic service is arguably among the fast-growing occupations in both industrialising and industrialised nations (Ehrenreich, 2000). It is a virulent offence against human rights, which has mostly been treated as a subset of irregular migration. It is, however, drawing the attention of policymakers as a labour issue involving "supply-demand" dynamics, and requiring data collection and policy appropriation (International Organization for Migration [IOM], 2005).

The "hidden" nature of the home environment makes it easy for child labour to go unrecorded (ILO, 1994). Of the children enduring the worst forms of labour, the less visible are children in domestic service. The social implications of subjecting children to domestic work are numerous and have inimical effects on the development of the nation. Victims may suffer physical and emotional abuse, rape, threats against self and family, and even death. Isolated from friends and family, they work for long hours. For them, educational opportunities are very rare. When they fall ill, they lack proper attention. In short, children in domestic service endure what International Labour Organization (2002) describes as hazardous or intolerable conditions. Their working in these conditions with little pay connotes child rights violations (UNICEF, 2006).

The literature is saturated with studies on children trafficked for the purpose of sexual exploitation (Altink, 1995; IOM, 1995; Bertone, 2000; International Labour Organisation/International Programme on the Elimination of Child Labour [ILO/IPEC], 2001; Lazaridis, 2001; Onyeonoru, 2003; Kelly, 2005; Laczko, 2005). These researchers highlight the push factors on the supply side. The scope of these works is rarely extended to other forms of exploitation, especially on the invisible children in domestic service. There is, 
therefore, the need to expand research to look beyond cross-border trafficking to other areas including internal child trafficking where knowledge is currently very limited. Employing children as domestic servants has a negative impact on the labour market, as it contributes to an irretrievable loss of human resources. Forcing children to work at an early age and subjecting them to long hours of work per day may deny them access to education, which is necessary to break the cycle of poverty and illiteracy that favours clandestine migration (Okereke, 2002). Domestic workers experiencing hard-working days may be objects of sexual exploitation in the household and can receive harsh treatment with life-threatening injuries (UNICEF, 1997).

Ibadan is among the major cities in South-West Nigeria where children brought from other parts of the country are employed in domestic servitude (United Nations Educational and Scientific Organization [UNESCO], 2006). Eleven out of the 33 local government councils have been designated as child trafficking endemic. Lutz (2002) has predicted that technological progress would eliminate the need for assistance from humans in households. This is an illusion in the face of practical reality. In Nigeria, documented information about the factors influencing the demand for domestic servants has yet to be fully explored. A way to check the use of adolescents as domestic servants is to dissect the propelling factors. This study, therefore, examines the components of household demand for domestic service in Oyo State, southwestern Nigeria.

\section{Context of Child Trafficking In Nigeria}

In the last two decades, there has been an increase in the internal trafficking of Nigerian women and children. Many people are trafficked from rural communities - Oyo, Osun, and Ogun States in the South West; Akwa Ibom, Cross River, and Bayelsa States in the South South; Ebonyi and Imo, in the South East; Benue and Kwara States in the North Central - to cities such as Lagos, Ibadan, Kano, Kaduna, Calabar, and Port Harcourt. Trafficking to these regions is predominantly for exploitative domestic work, farm labour, and prostitution (UNICEF, 2006).

In Nigeria today, the rate of child abuse has assumed a worrisome and alarming proportion (Semenitari, 1998) attracting the attention of the federal government in its establishment of the National Agency for the Prohibition of Traffic in Persons (NAPTIP) in 2003. Child abuse has degenerated into a form of slave trade. According to Ariyo (2001), the phenomenon of child trafficking for forced labour or compulsory labour is growing so fast that most countries in Africa fit into one of the categories as sender, transit, or receiving countries. Persons are trafficked for prostitution, and to work as domestic servants, bus conductors, and street traders. They are exploited in agricultural work, brass melting, stone digging, and scavenging. Urban migration and poverty have saturated the labour market, especially the informal market, and led to the systematic reduction of the cost of labour. As a result, cheap labour in the informal sector, particularly domestic labour, grew as the economic crisis forced every member of the family to work outside their homes to sustain family finances (UNICEF, 2006).

Although endowed with rich natural resources and extensive human resources, Nigeria has not developed the necessary technological, industrial, managerial, and political know-how to pull its resources together in a sound economy to take care of the basic needs of its population. As a result, poverty and hard living conditions are prevalent, affecting children in particular. The severe economic and social deprivation has made poverty rampant in, 
especially, Third World countries. The situation in Nigeria has reached an alarming stage, as more than $45 \%$ of the population live below the poverty line, while $67 \%$ of the poor are extremely poor (Central Bank of Nigeria, 1996).

The Nigerian economy has made the situation worse for the children of the poor, whose parents have either lost a job or suffered a dramatic decline in income (Olukoshi \& Aminu, 1990). Problems such as malnutrition, high infant mortality, and overcrowding have been exacerbated, as many families are pushed below the poverty level, even as a small class of people profited from the crisis. Worse still, many parents have to leave their children to their fate. These children may have to find out a living for themselves. The hope of continuing education or working abroad, traditional migration patterns of labour within the country, and the practice of children being loaned or sent to better-situated family members to be raised, have contributed to the increasing rate of child trafficking for domestic service (UNICEF, 2006). The outcome of this is highly visible in Nigerian cities with the employment of children in various child-labour activities.

The practice of child labour in Nigeria has become one of the nation's most pressing problems. Young children are placed into homes to serve as domestic servants; their wages may be collected by their sponsor (Olateru-Olagbegi, 1997; Tade, 2010). Scholars have also demonstrated how children become domestic servants and are seconded to trade at strategic spots by their employers or foster parents (Isamah \& Okunola, 2003). However, the exact number of those involved is not known owing to the fact that the cases are not reported to the authorities and are shrouded in highly secret networks (Tade, 2010).

Young women are trafficked within Nigeria and to other West African countries (such as Cameroon, Gabon, Guinea, Mali, and Côte d'Ivoire) for domestic work, sex work and street vending. Children from Nigeria's southern and eastern states are trafficked to cities in the north and west and to other West African countries for exploitation as domestic servants, street hawkers, and forced labourers. Although the Nigerian government has developed several mechanisms to address the issue of trafficking, especially for sexual exploitation abroad, little or no attention is being paid to domestic trafficking including the other forms of exploitation in Nigeria. This has contributed to increased suffering and exploitation in a sector that is hidden from the sight of the public, an invisible parade of the most inhuman forms of exploitation in history.

Children working in domestic service are invisible and difficult to survey by social welfare officers. Most of these children are in their teens, while some barely above 9 or 10 and are mostly serving as domestic servants in the households of higher educated persons or wealthy businessmen. Various forms of child labour activities are found throughout the informal sector in Nigeria, particularly in the cities (Hodges, 2001). These children engage in three broad categories of work: markets and streets, cottage industries and mechanical workshops, and domestic service in private households. The above review shows that the empirical study of the plight of these children trafficked into domestic service has been limited to the supply side. Therefore, there is a need to understand the demand side of the equation and to fill in the knowledge gap.

\section{Research Setting: Ibadan}

Ibadan is the capital of Oyo State, Nigeria. Oyo State with the label "The Pacesetter State”, came into existence as a consequence of state creation exercises embarked upon since 
independence in 1960. The Western Region was one of the three regions created by the Macpherson Constitution of 1954, which introduced a high level of autonomy for the regions. The Western Region government was headed by the late Chief Obafemi Awolowo, the first Head of Government and later Premier. The region attained internal self-governance in 1957 as a prelude to the political independence of the country in 1960. The old Western Region was reduced to the present entity called Oyo State with its capital in Ibadan after several other states were carved out of it. Founded in 1829, Ibadan was, until 1970, the largest city in subSaharan Africa. Ibadan, at a time, was settled at Oja'ba, a site very near Mapo Hill. The people of Ibadan were successful warriors who needed the hill, which afforded them better defence. Ibadan has been an important administrative centre since colonial times. It was the capital of the old Western Region from 1946 to 1967; the old Western State, 1967 to 1976; and Oyo State, 1976 to date (Afolayan, 1994).

According to the 2006 Census, Oyo State has a population of 5,591,589, with male and female populations of 2,809,840 and 2,781,749, respectively. It has a growth rate of 3.4\% (Federal Republic of Nigeria, 2007). Apart from the issue of the predominant occupations in Ibadan, which include trading, agriculture, craftsmanship, and engagement in formal public and private sectors, Ibadan was chosen for this study because of its status as the destination of many trafficked children (UNESCO, 2006).

The core population of Ibadan is Yoruba, but its population has always been ethnically mixed and is becoming increasingly so. Although industry is less developed in Ibadan than in Lagos or Kano, there are many traders and artisans, which service many needs of the city (Okafor \& Amayo, 2006). Ibadan also has Nigeria's first university, the University of Ibadan, which contributes a significant intellectual, professional, and artistic profile to its economy. There are notable ethnic and class variations. In summary, Ibadan encapsulates so many characteristics of modern Nigeria (Guyer, Denzen, \& Agbaje, 2002; Agbaje, 2002).

\section{Methods}

The study adopted a mixed approach of data collection, analysis, and interpretation. This involves mixing both qualitative and quantitative methods of data collection and analysis. Mixing different methods strengthens and reveals various aspects of empirical reality and defuses the shortcomings of using a lone method in a research study (Cresswell, 1999). Moreover, social phenomena are so complex that different kinds of methods are needed to enhance understanding of these complexities (Greene \& Caracelli, 1997). The research adopted Sequential exploratory design. This strand of mixed method design prioritises qualitative over quantitative data. The intent was to first explore the factors underlying the demand for domestic servants in households. This exploration was helpful, as it facilitated the development of a survey questionnaire for a larger population of respondents. The survey was both open- and close-ended.

To select our sample size, Ibadan South West, Ibadan North East and Ibadan North Local Government Areas (LGAs) were chosen purposively. The Oyo state anti-trafficking committee categorised these LGAs as recipients of children used for domestic service (Tade, 2010). A combination of methods was used to select respondents for the study. Mixed methods sampling involves the selection of units or cases for a research study using both the probability sampling and purposive sampling strategies. Qualitatively, the snowball method was used to reach 15 demanding households. Based on a household survey, 15 households were randomly selected from the three LGAs (5 from each). Each of these LGAs was 
clustered into three neighbourhoods based on the socio-economic status of inhabitants. For instance, in Ibadan North, Bodija, Bashorun, and Agodi were the selected neighbourhoods, while Odo-ona, Oluyole, and Adeoyo were selected from the Ibadan South West Local Government. In each locality, employers were reached through the help of neighbourhood informants. We relied on the familiarity of informants to identify households where domestic servants were employed. After reaching the first employer, other employers were located through the snowball method.

Stratified purposive sampling was used to identify private and public organisations in selected localities. Copies of the questionnaire were given to women working in banks, government parastatals, schools, hospitals, law firms, and women in broadcasting. Out of the 800 copies of the questionnaire distributed, 528 were returned. Of these, 140 indicated having domestic servants and were used primarily for this study. The questionnaire probed into the job status of women, with particular attention to whether they started paid employment before or after marriage, time of closing at work, and the reasons for working. We also probed into husbands' support for working wives (the coping strategy for husband disapproval, husbands' occupations, and locations), reasons for engaging domestic servants, and preference for the third party (relatives).

In all, 15 in-depth interviews (IDIs) were conducted. We also utilized the information obtained from five key informants (community leaders and welfare officers). The interviews were mainly conducted in specific institutional settings, like offices, churches, houses, and recreation centres. The informants sometimes accompanied the researchers to the respondents' preferred interview settings ${ }^{1}$ to assure our respondents that the interview was purely for academic purposes and not to coordinate their arrest ${ }^{2}$. Interviews conducted outside respondents home were carried out as agreed to by the respondents. Each respondent was contacted through referrals and venues were arranged for the interview. The in-depth interview guide probed into: workload at work and household levels; job status and nature of job; husbands' disposition to the engagement of domestic servants; preference for relatives and family size.

The interviews were conducted with a digital audio recorder which facilitated the download of the recorded conversation onto the computer for editing. The audiotaped interviews were then transcribed to enhance accuracy, dependability, and the integrity of the data analyzed. Thus, because the audiotaped recordings - not the transcripts - are the data, a methodical listening to and reviewing of the recorded interactions was done to make details visible in order to reach agreement. Stop-checking of the transcribed tapes was done to ensure the trustworthiness and validity of the interviews. The texts selected for transcriptions were considered because of their analytical contributions to the study.

Owing to the nature of the topic under investigation, a listening guide was adopted in order to read the reflexively constituted narratives, relational narrated subjects, and

\footnotetext{
${ }^{1}$ Interviews were conducted in the environments chosen by respondents where they thought they could freely express their opinions. Also, getting employers to interview on the topic was tedious except when conducted in preferred settings. However, the researcher still had the opportunity of visiting the respondents in their households after a level of confidence was established.

${ }^{2}$ In Nigeria, the National Agency for the Prohibition of Traffic in Persons (NAPTIP) criminalises the employment of persons under the age of 18 as domestic servants outside their immediate family environment. Arrest and conviction attracts N100, 000 fine or imprisonment for a period of five years (see Section 10, Subsections D \& E of the NAPTIP amended Act, 2005).
} 
constructed and critical subjects. First identified were basic elements of narrative analysis, such as recurring words, themes, events, chronology of events, protagonists, plot, subplots, and key characters. The next stage in the analysis was to attend to the way in which the subjects spoke about themselves and the parameters of their social world, taking into consideration how the respondents change personality from the use of "I", "we", "you”, or "it", which could demonstrate varied meanings with respect to perceptions of the self (Stanley, 2002). Thirdly, the respondents' narratives were also considered as relational, looking for social networks. This is in line with Somers and Gibson's (1994) notion of "analytic rationality", where all narrated subjects are understood as intrinsically relational and as part of networks of relations. After all the sorting and consequent content analysis, respondents' narratives were then reproduced accurately. Descriptive statistics was employed to analyse the quantitative data, while the qualitative data were content analysed.

\section{Results}

\section{Socio-Demographic Characteristics of the Respondents}

Table 1 presents the socio-demographic characteristics of the respondents. Most of the working women (91.5\%) fell between ages 20 and 50 years, an age range where a lot of women would be working and might require the services of domestic servants. As the women pass 51 years of age (8.5\%), the need for company may become a necessity.

As regards ethnic distribution of the respondents, the Yoruba populated the study, representing $84.7 \%$, perhaps because of the research setting, which is predominantly a Yoruba state. The Igbo were 6.1\% while Edo had 4.2\%. Other ethnic groups had only 5.1\% of the distribution. On income distribution, 16.9\% earned between N10,000 to N20,000 monthly, while $27.1 \%$ earned N51,000 and above. 
Table 1: Socio-Demographic Profile of the Respondents

\begin{tabular}{|c|c|c|}
\hline Age & Frequency & Percent \\
\hline $20-30$ & 73 & 13.8 \\
\hline $31-40$ & 217 & 41.1 \\
\hline $41-50$ & 193 & 36.6 \\
\hline 51 and above & 45 & 8.5 \\
\hline Total & 528 & 100 \\
\hline \multicolumn{3}{|l|}{ Ethnic } \\
\hline Yoruba & 447 & 84.7 \\
\hline Igbo & 32 & 6.1 \\
\hline Edo & 22 & 4.2 \\
\hline Others & 27 & 5.1 \\
\hline Total & 528 & 100 \\
\hline \multicolumn{3}{|l|}{ Income } \\
\hline $10,000-20,000$ & 89 & 16.9 \\
\hline $21,000-30,000$ & 123 & 23.3 \\
\hline $31,000-40,000$ & 87 & 16.5 \\
\hline $41,000-50,000$ & 86 & 16.3 \\
\hline 51,000 and above & 143 & 27.1 \\
\hline Total & 528 & 100 \\
\hline \multicolumn{3}{|l|}{ Education } \\
\hline Primary school & 2 & 0.4 \\
\hline Secondary & 61 & 11.6 \\
\hline Tertiary & 413 & 78.2 \\
\hline Others & 52 & 9.8 \\
\hline Total & 528 & 100 \\
\hline \multicolumn{3}{|l|}{ Religion } \\
\hline Catholic & 40 & 7.6 \\
\hline Protestant & 85 & 16.1 \\
\hline Pentecostal & 315 & 59.7 \\
\hline Islam & 69 & 13.1 \\
\hline Others & 19 & 3.6 \\
\hline Total & 528 & 100 \\
\hline \multicolumn{3}{|l|}{ Marital Status } \\
\hline Married & 457 & 86.6 \\
\hline Consensual Union & 14 & 2.7 \\
\hline Widowed & 25 & 4.7 \\
\hline Separated/divorced & 32 & 6.1 \\
\hline Total & 528 & 100 \\
\hline \multicolumn{3}{|l|}{ Type of Marriage } \\
\hline Monogamous & 433 & 94.7 \\
\hline Polygamous & 24 & 5.3 \\
\hline Total & 528 & 100 \\
\hline \multicolumn{3}{|l|}{ Children } \\
\hline $1-2$ & 163 & 35.6 \\
\hline $3-4$ & 244 & 53.3 \\
\hline Above 4 & 51 & 11.1 \\
\hline Total & 528 & 100 \\
\hline \multicolumn{3}{|c|}{ Length of Marriage (years) } \\
\hline $1-2$ & 28 & 6.2 \\
\hline $3-5$ & 61 & 13.5 \\
\hline $6-10$ & 110 & 24.3 \\
\hline $11-15$ & 89 & 19.7 \\
\hline Above 15 & 164 & 36.3 \\
\hline Total & 528 & 100 \\
\hline
\end{tabular}

Source: Survey, 2011

Regarding education, $78.2 \%$ of the participants had tertiary education, $11.6 \%$ had secondary education, while $0.4 \%$ had primary education. This implies that the majority of the respondents were literate enough to make well-informed decisions. Besides, most of the working women were Pentecostals (59.7\%), 16.1\% were Protestants, 13.1\% were Muslims, 
while the Catholics were 7.6\%. A large percentage of the women were married (86.6\%), while $13.4 \%$ were either in a consensual union, widowed, separated, or divorced. Also, a greater proportion (94.7\%) had a monogamous marriage while $5.3 \%$ had polygamous marriages. The distribution by number of children revealed that $53.3 \%$ of the respondents had between three and four children, 35.6\% had between one and two children, while $11.1 \%$ had more than four children. About 36.3\% had been married for 15 years and above, 24.3\% had been married for between 6 and 10 years, while 19.7\% had been in conjugal relationship for below 5 years.

\section{Types of Employers and Reasons for Hiring Domestic Servants}

The study identified three categories of employers of domestic servants. They are classified based on the family phase and structure:

1. Starter family type: This type comprises the newly wedded and those with immature children who need extra care and are working. This type involves the first and second phases of family cycle.

2. Transiting family type: This is in the third phase of family cycle. The families have children who are grown up who could take up responsibility.

3. Mature families: This category occupies the fourth and fifth phases of family cycle. It is composed of pensioners, families with adults, widows, and working women who are grandmothers.

The Starter Household. One of the desires of newly wedded women in contemporary Nigerian society is to ensure strong bonding relationships with their husbands at the outset of their marital life ${ }^{3}$. They would prevent early intrusion in any form (family, friends or any other third-party interference). Getting pregnant and being employed bring the simultaneous challenges of keeping the home while fulfilling work demands; the ability to perform domestic chores and work effectively becomes problematic. Hence, the woman who initially considered the presence of a third party in her home as repulsive may have a second thought. The couples basically mull two options over: inviting a relative to assist or getting a domestic servant who can be paid. The former option is rejected because of the cultural obligations attached to having a fostered child. Also, the starter household ruminates on keeping their domestic affairs away from family members which can only be guaranteed by a servant who in not a relative.

Apart from these, employers prefer a master-servant relationship. Interviews with employers revealed that beating a relative and subjecting him or her to ill treatment could threaten the family bond and solidarity. The cultural obligation attached to having a relative has also affected the fostering practice in Nigeria. According to the respondents, the demands of having fostered children are enormous, especially if the fostered child is an orphan. Such a child needs care and must be pampered. Over-labouring such a child could create further emotional trauma. The household is then burdened, rather than being relieved. Hence, a paid domestic servant who could be treated ${ }^{4}$ according to the whims and caprices of the employer

\footnotetext{
${ }^{3}$ Young couples cherish intimacy in their marriage and so have been found to distance themselves from members of their extended family.

${ }^{4}$ This means being subjected to all sorts of inhumane treatments. Respondents said they could use the domestic servants "anyhow" because he or she is being paid to render a service. This is practicable in Nigeria because the practice is hidden from the public glare. The domestic servant is at the mercy of her employer. While the agent is interested in exploiting the child for money, the employer is interested in the labour exploitation of the domestic servants.
} 
is favoured. Thus, for the starter family, the pretext for demanding domestic servants is workload created by role strain. This was captured by an employer:

Well, the reason is not far-fetched, the way the country is going now, and one person working is not enough to sustain the home. So you find out that we women, too, are working and our working is not just limited to one, you find us doing extra businesses, like for me I make "sobo". For me to go to work in the morning, I have to leave by 7:00 a.m. because I have to do school runs, get back home 5:30 p.m. or 6:00 p.m., I'm fatigued. Apart from that, I personally don't like kids coming with me to the office except if it is exceptionally necessary. So, most of us who have kids in the same school have a routine arrangement for our children. Somebody does the school run (takes the children to school) in the morning and another person does the school run (pick the children up) in the afternoon back home. The essence is for the children to have somebody to stay with them at home in the afternoon and the person can take care of them and then, of course, when I get back from work at least some part of the dinner is ready or totally ready. Cleaning of the house, washing the clothes, etc., if one has to do it on a weekly basis, you find out that you are spending more than if you have somebody in-house that is able to do most of these things and, of course, you are paying a monthly wage to the person. (IDI, Female, Bashorun)

Age is a contributing factor to household demand for domestic servants (Tade and Aderinto, 2011). Human needs are, to a certain extent, age specific. Hence, the needs of newly married women differ from those with grown-up children. Owing to their youthfulness, newly married women take up paid employment which may create pervasive systemic dilemmas for them in fulfilling expectations as mother, wife, and worker. A respondent stated the following in an in-depth interview session:

I never liked the idea of bringing in a third party into my house because I found it difficult to want to open my family to outsiders but when we started bearing children and I have to go to work, I had no choice other than to secure an extra hand to help with the domestic demands. (IDI, female, Bodija)

Location of the husband's job may also influence the demand for a domestic servant. We found that women complained of boredom whenever their husbands leave for their work stations outside the state. They may return home on a monthly basis considering cost. Durkheim discusses the effects of mechanical solidarity in modern industrial societies. It reduces the "conscience collective" where people think of themselves as "I" not as "We". Hence, people live in community but with limited interaction. They also live far away from their relatives once married. A respondent recounted:

For somebody like me who does not have her husband around and unfortunately the last born of my family [meaning she cannot go and bring a relative to stay with her again], I need somebody to talk to at my level and somebody who can give me a second opinion no matter how childish it might sound. There must be somebody around who I can brainstorm with, not me alone. (IDI, Female, Bodija)

Nigerian men, by virtue of tradition and associated social and cultural factors, have profound influence on their wives and on decisions about family life. Patriarchy and patrilineal traditions place men at a dominant position in the society and family (Isiugo-Abanihe, 2010). Consequently, some men disapprove of their wives working outside the home. This is 
because women in contemporary society still bear extensive responsibilities for care of the household and children. As Scanzoni (1978) avers:

the wife's role, although theoretically significant, has not revealed its prime import in any direct linkage to the larger society. Whereas the husband's behaviour is significant in both the occupational and the conjugal settings, the wife's has been generally significant only within the latter. (pp. 1-2)

From an African point of view, mothering has traditionally been located within the domestic spaces of home and family. Women who take up jobs are, therefore, seen as challenging the existing norms and assumptions surrounding their mothering role, with serious implications. Ėrínoshó (2005) claims that a wife and mother who works must be withdrawing from the care of her home and children time and attention which they are really in need of. Hiring domestic servants becomes a safety valve to help muddle through multiple roles. In his classic essay, Merton (1957) notes that:

The notion of the role-set reminds us, in the unlikely event that we need to be reminded of this obstinate fact, that even the seemingly simple social structure is fairly complex. All societies face the functional problem of articulating the components of numerous role-sets, the functional problem of managing somehow to organise these so that an appreciable degree of social regularity obtains, sufficient to enable most people most of the time to go about their business of social life, without encountering extreme conflict in their role-sets as the normal, rather the exceptional, state of affairs. (p. 111)

Cognisant of the cultural and social expectations and the need to accomplish observable social regularity and order in the domestic sphere, women negotiate with their husbands to reduce the "burden of roles" by outsourcing some tasks. The view of the respondent below captures this:

at that time...I was left alone once he travels. I was desperate at having someone who I could be chatting with in the house apart from the fact that she has to sweep the floor and wash plates. My husband runs a private business and I was already working as soon as I finished my service year. The work became too much. How can you say I should wash the plates, clean the house, prepare the food, etc. The housework is not easy for women. One needs assistance. Even though I had not given birth, I still had a lot to do and still must go to work. (IDI, female, Mobil)

The number of children and their ages become critical factors in deciding whether to hire domestic servants or not. The domestic task increases with the number of children; the age determines the attention that is required for the child(ren). Pregnant wives also risk miscarriage when burdened with work. This may necessitate the need for assistance.

The reason was that I was pregnant, creating the need for somebody to start taking care of the children. All along, I have sisters and another relative living with me but they have all left for school. Their absence created a vacuum and when I took in (became pregnant), it was obvious that I needed somebody to assist me so I will not cause complications by overworking. I already have three children and you know 
what that implies with their ages, and my work and husband to care for in the house? (IDI, female, University of Ibadan)

The quantitative data (Table 2) corroborates the findings of the qualitative data. The respondents were asked to give reasons for engaging domestic servants in their households. Performance of domestic chores and duties were the main reasons for the demand for domestic servants. The analysis of the responses showed that $63.6 \%$ of the working women hired domestic servants to perform household chores/domestic work/washing/cleaning of the house, while $24.1 \%$ employed domestic servants to care for their children.

Inundated by role-strain, households adjust structurally to accommodate a childcare facility when the mother is not around. Since there is no welfare package for working women in Nigeria to reduce their workload, engaging domestic servants may be a veritable option. Further, the intensified economic slump has made the money that women earn vital to household survival. Domestic activities could be time consuming and energy sapping. Thus, it may be difficult for women to effectively cope alone with the multiple tasks without assistance. Thus, the yoke of domestic labour on women has far-reaching consequences for all spheres of their lives.

Table 2: Reasons for Engaging Domestic Servants

\begin{tabular}{l|ll}
\hline Reasons & Frequency & Percent \\
\hline Child care & 33 & 24.1 \\
House chores/domestic/house care & 76 & 55.5 \\
Washing/cleaning & 9 & 6.6 \\
Run errands & 9 & 6.6 \\
Cook & 2 & 1.5 \\
Driving & 1 & 0.7 \\
For assistance & 7 & 5.1 \\
Total & 137 & 100.0 \\
\hline Sour: Survey, & &
\end{tabular}

Source: Survey, 2011

The Intermediate Household. Unlike among those in the age range of 21 to 30 years, demand for domestic servants is lower among working mothers between 31 and 50 years owing to the presence of grown-up children who can help with the workload. They constitute families in transition, as they have children who could take up some responsibilities. However, it was found that transitioning households are more likely to outsource domestic duties, which become more complex tasks as the children grow to attend schools while the parents are absent owing to the nature of their work. This is, however, evanescent. The need resurfaces as soon as children leave for school or set up their own family through marriage. The attention of the household is shifted from tendering the baby to nurturing the grown-ups through enrolment in educational institutions. The children do not return home early to perform domestic chores, as they continue with after-school lessons. Hence, the mother returns from work tired and with unfinished domestic chores. 
Women in the work force are today expected to bring to their jobs all the energy, talent, and motivation that employers have long expected of men, in addition to a willingness to work full time, and a readiness to perform tasks that often require putting the needs of the employer over and above those of the family. Okafor and Bode-Okunade (2003) contend that employers in Nigeria demand from their employees total loyalty without modifying work schedules for any gender including working women. These pressures co-exist with demands at home from husbands and children who clamour for attention to their needs. As a result, the ambitious and conscientious employee, wife, and mother may find herself caught in a web, a classical case of role conflict in which she is pulled in opposite directions. This is so because while the social and economic characteristics of modern living have changed, the economic roles of housewives, compelling them to engage in work outside the family, and the traditional expectations regarding their conjugal and maternal roles have rarely changed to account for their new traditional roles. Hence, while a career husband may do little more than his formal occupational demands, the housewife combines both the burden of occupation and the housework, which is neither economically recognized nor statistically accounted for.

The Mature Household. The need for companionship is the essential factor propelling widows, pensioners, and the aged to request the services of domestic servants. The type of residence pattern which modern families have adopted (to live far away from their parents) further heightens the need for companionship. Another reason is difficulties faced by the elderly in performing certain seemingly difficult domestic tasks. The aged among the respondents lamented that most of their children were grown up. They reported that they were either married (families of procreation) or living far away from their families of orientation. The domestic servant, therefore, becomes necessary as a panacea to survive before their children and wards come around. A respondent put it this way:

I think domestic servants are better, especially for older people when their children have left. Older people hire domestic servants when their children are no more around in order not to feel lonely, not necessarily because of the household tasks. They may not be doing bigger tasks. For instance, the one I have with me now in-house is pregnant and she decided on her own to come because she believes that the husband would not be able to provide all that she needs before she puts to bed. I think that is the reason she decided to work as house-help. All she does is to go to the husband to get money for the antenatal care. I don't think there is anything important this one can do for me other than to keep me company in the house. In another 15 minutes, she may be sleeping, she is not doing anything big per se, but she enjoys staying here and we do things together. So, it is very necessary for the elderly to have at least one or two for companionship not because of any other motive. So I understand what the government is saying but that is what we call necessary evil. We need them except if government wants to deceive themselves. In the olden days, older people lived among family members but that is no longer the case nowadays. Even the Ibo people don't go home anymore. Many of them who retired in U.I. have houses in Ibadan. They said they don't know anybody there. So, nobody wants to go home, since they don't go home frequently. But when the children go, what will happen to them [Parents]? So they need people to stay with their parents. The federal government should realize that they are going to grow old. (IDI, female, Bashorun)

Most women in this category are above 50 years of age where the burden of loneliness is more heightened. They may even be widows and left alone in a large house, 
which has implications for their health. This is a departure from the cultural past. In traditional African society, the aged resided with their families and were adequately cared for. The family has been the safest haven for the aged. Its ties have been the most long-lasting and, on them, the aged have relied for greatest security. The respondents however, reported that modernisation has obliterated this traditional norm, hence the elderly are isolated. The need for companionship explains man's desire to live in groups and avoid isolation or solitude. The presence of domestic servants may not be anchored by this group on a strong need for task performance but for social interaction. According to a 72-year-old widow and retiree:

I think domestic servants are better for older people when their children have left. Older people hire domestic servants when their children are no more around in order not to feel lonely, not necessarily because of household tasks. (IDI, female, Bashorun)

\section{Cost}

The financial capacity of households is critical to the demand for domestic assistance. The ability to pay for outsourced domestic assistance increases with the increase in monthly income of the employers of domestic servants. Financially cozy households will effortlessly be able to subcontract domestic activities. People who earn more than N51,000 and above per month are more likely to employ domestic servants than other categories of income earners. This is because employers pay between N5,000 and N6,000 (\$40) to hire a domestic servant. Owing to the dwindling economic fortunes and poverty in Nigeria, paying for domestic servants may be difficult for those earning below N51,000. The qualitative data further revealed that household earnings are considered important when hiring domestic servants. This view was well captured by an employer:

Yes, I need an extra hand in the house to help me take care of my little baby while I go to work but we also have to look at the economic implications of bringing in an extra hand. For instance, my husband earns N36,000 monthly, while I earn N26,000 monthly. Thus, I need to engage myself in other buying and selling in order to meet additional needs of the family like that of paying for domestic servants. (IDI, female, Adeoyo)

The employers further spoke about the amount of money being "charged” by agents per domestic servant:

In those days, I was paying as low as N400 naira to my domestic servant. But nowadays, we pay from N4,000 to as much as N7,000 to get house-help. And then you will have to pay for an extra month to represent money for conveying the domestic servant from wherever state. (IDI, female, 54 years, Apata)

The contribution of women to the household production becomes important to complement husbands' inputs. As a result, most husbands (87.7\%) supported their wives' decision to work to supplement their earnings to keep the home going because of the economic situation, while others work for self-actualisation. This concurs with earlier findings that women's economic contribution to household income improves the economic well-being and standard of living of the household (Martin \& Roberts, 1984; Kamerman, Neumann, Waldvogel, \& Brooks-Gun, 2003; James-Burdumy, 2005). 
Intermittent work-related travels of household heads could have profound effects on the social regularity of households. Such travels bring strain into the demands of both family and work commitments. Earlier studies call this "intermittent husband syndrome" (Morrice, Taylor, Clark, \& McCann, 1985; Rigg \& Cosgrove, 1994), which involves the spouses and children of workers who are often away from home. Men are more likely to embark on work travels if there is security from their wives to take care of the home.

\section{Husband Factors}

Sixty percent of the sampled working women said their husbands supported their decision to work, while $40 \%$ said their husbands did not support their decision to work. This implies that a husband's support for his wife's work affects the demand for domestic servants. Husbands' approval for wives' work may be as a result of the anticipated input derivable from the work. Close to $60 \%$ of the working women stated their decision to work was mainly driven by economic factors, to earn a living and support their husbands in the home management.

The performance of the gendered roles is germane to the maintenance of order in the home. The outsourcing of domestic duties becomes a coping strategy in homes where working mothers are stretched between salaried jobs and culturally prescribed roles without supportive husbands. Typical household tasks, such as kitchen work, care for the children, the fetching of water, ironing, washing, and weeding are fundamental to proper household functioning. Conversely, households where husbands assist in performing domestic duties may not see the need for a domestic servant.

Most respondents (70.3\%) indicated that their husbands assisted them in the performance of domestic duties. Assistance from husbands may result from time allocations between the partners. Another possible explanation for such assistance could be partners' contributions to the sustenance of the home. Gershuny, Godwin, and Jones (1994) claim that household tasks are allocated on the basis of the amount of time available to each partner. Thus, if men do little work in the home, it is because their time is taken up in paid employment, sometimes referred to as the "breadwinner trap" (Baxter, 1992, p. 166). Husbands earning high incomes are considerably less likely to do housework than husbands earning lower incomes. "The best predictor of a husband's assistance with housework is his success as an income provider"... "the higher the wife's status, relative to her husband's, the more likely she is to work outside the home and the more likely he is to perform tasks in the home” (J. Ericksen, Yancey, \& E. Ericksen, 1979, p. 311).

\section{Theoretical Framework and Further Discussion of Findings}

The Preference Theory helps to explain the various choices women make with respect to the kind of childcare facility preferred, following the kind of activity (work) they (women) are involved in. This is because childcare is within the purview of women. Hakim (1996, 2000, 2002) used this theory to explain women's choices between work in the home and work in the market and to predict the future patterns of these choices. Although developed to explain patterns of female employment, its applicability to men is not limited. The theory has four tenets:

1. The world has changed in ways that give women in postmodern societies real choices about how they combine employment and family; 
2. Given freedom to choose, women make different choices;

3. Women's heterogeneous preferences and priorities create conflicting interests between groups of women; and

4. These groups of women differ substantially in their responses to employment and family policies and conditions.

Hakim (2000) argues that men's preferences and priorities are more homogeneous than those of women, which gives men an advantage in negotiations over work and family choices, and, ultimately, accounts for the continued success of patriarchy. But women, according to preference theory, are not simply buffeted by social structures and patriarchy; rather, they decide on and pursue their own agenda. Women and men can only realize preferences if the goals they prefer are available to them.

Hakim (2000) argues that the main determinant of women's heterogeneous employment patterns and work histories is heterogeneity in their preference for differing combinations of family work and paid employment. She adds that women have genuine choices about how they wish to live; there are no constraints limiting or forcing their choices; and moreover, the lifestyle choices of women are now more important than the constraints associated with social structure, class, or other macro-level influences. Hakim further classifies women into three categories based on their work-life preferences:

1. Home-centred women, for whom children and family life are the main priorities throughout life;

2. Adaptive, non-career-oriented women who wish to combine work and family or who have unplanned careers; and

3. Work-centred women, for whom employment or the equivalent is the main priority in life.

Home-centred and work-centred women are said by Hakim (2000) to be characterized by a "consistent commitment to their chosen life-goals"; work-centred women are frequently childless but may also have children, as men do "as an expression of normality, and as a weekend hobby" (p. 164). Adaptive women are a highly diverse group and include those who may not marry or marry only late in life. Although such women may work full time throughout their lives and achieve high-level career success, "their adaptiveness comes from a lack of commitment to a career from the start” (p. 166).

In categorizing women into work-centred, family-centred, or adaptive, Hakim (1996) argues that employment careers are centrally important for only a minority of women. Today, among university graduates, more than half of adult women accept the sexual division of labour and treat market work as an additional secondary activity to be fitted in with the demands of domestic life. However, it does not follow that this pattern of behaviour is unconstrained. All women face constraints in making decisions about their lives. All nontrivial decisions have opportunity costs as well as real costs. Moreover, to say all women encounter constraints does not render the existence of barriers to genuine choice empty or banal. Some women have substantially better chances of overcoming constraints and, hence, of living as if they faced no constraints.

McRae (1993) argues that the constraints facing women in choosing how to balance market work and family work, or to forgo one in favour of the other, tend to fall into two categories: normative and structural. Into the former, according to McRae, come women's 
own identities - their "inner voices" - gender relations in the family, and husband's/partner's attitudes. Perhaps, the most immediate structural constraints affecting mothers' choices are job availability and the cost and availability of childcare, but the outcomes of different social origins also curtail choice more sharply for some women than for others, acting either through poor educational qualifications, early pregnancy, poor health, or culture.

In applying this theory to the study, the trichotomisation of women with repect to preferences in lifestyle choices becomes paramount in influencing whether a household may make a request for a domestic servant. Adaptive mothers may still prefer the presence of house-helps to fill their gap when away to work. Besides, women may use domestic outsourcing as a tool to negotiate and secure their husbands’ approval to engage in paid labour.

The results of this study have shown that demand for domestic servants is influenced by work status of the woman, workload, childcare considerations, financial cost, a supportive husband, and the need for companionship. The findings are attributable to the incursion of women into salaried jobs, driven by economic considerations. This domain (public), hitherto regarded as an exclusive preserve of men in Nigeria (at least in the cultural definition of breadwinner) has seen visible female presence (Tade, 2010). According to Onyeonoru and Fayankinmu (2005) and Onyeonoru (2005), the number of working women and working mothers was on the increase. Otite and Ogionwo (1979) estimated that half of Nigerian working women would be wives and mothers.

The Beijing Declaration of 1995 affirms countries’ commitment to the inalienable rights of women to participate in all spheres of life including economic domain. Economic growth and development is greatly dependent on a number of factors, especially for an economy like Nigeria, which has witnessed various levels of decline in growth of some sectors. Notwithstanding the international declaration on the rights of women, the performance of domestic duties is still held constant. Hence, working women negotiate the employment of a domestic servant to reduce the stress of formal employment.

The finding on how workload can influence the demand for domestic servants is consistent with the literature. Van der Lippe (2007) notes that balancing work with family has become one of the most important issues for families. She posits that, with both spouses having paid jobs, difficulties arise as to who is responsible for the domestic and caring duties at home. At the other end, organizations want full loyalty from their employees. Owing to the escalation of time in the family and workplace (Epstein, 2004), most women feel torn between the two sectors because job expectations and parenting standards have become more demanding (Daly, 1996; Moen, 2003). Hochschild (1997) notes that modern workplaces force their employees to spend more time at work than at home, such that work becomes home and home becomes work. The implications of these work-home conflicts are time pressure, fatigue, burnout, and health problems (MacDermid, 2005). Coser (1973) describes households and workplaces as greedy institutions. During family formation and career mobility, paid work and domestic work demand time and energy (Glass \& Camarigg, 1992). The greater the time demands of paid and domestic work, the more employees experience work-family conflicts (Voydanoff \& Kelly, 1984). One way to combine paid and domestic work is by outsourcing domestic chores and caregiving (Van der Lippe, 2007). Hence, domestic outsourcing is a rational escape from a work-family quagmire. Hutton and Giddens 
(2000), in their discussion of the impact of globalization on the modern family, note that "the growth in personal household services is the result of the emergence of two-earner households who have to buy in services because the woman is not at home” (pp. 5-6).

The findings can also be anchored and explained by functionalist role theory. A "role" refers to a set of societal expectations on an individual. By unspoken consensus, certain behaviours are deemed "appropriate” (e.g., looking after the home by women) and others "inappropriate” (abandoning domestic duties for paid employment in African settings). For example, it is appropriate for a woman in an African setting to take up her prescribed mothering and wife roles. Abandoning these traditionally prescribed roles is negatively sanctioned. Sociologists speak about different kinds of roles (gendered or cultured). In Africa, the social role of a wife and mother is both gendered and culturally defined and sanctioned.

Fundamental to the role theory is the emergence of role strain upon working mothers. This role pressure may arise when there is a conflict in the demands of roles, such as work demands versus household demands and tasks. By taking up jobs outside the home, working mothers deny members in the domestic sphere (husband and children) the traditionally prescribed attention and care which they are really in need of. Hence, working mothers may negotiate with their husbands to get a third party (a domestic servant) to assist in the performance of domestic chores and childcare which may be suffering because of her job demands. Thus, hiring a domestic servant becomes a safety valve for women who face conflict between achieved and ascribed social roles.

\section{Conclusion}

Owing to the stiffening economic realities in Nigeria, women have become active economic partners in households. Such labour dualism affects the effective performance of female roles in modern households in either sphere. The categories of employers (the aged, the newly married, and the transitional households) in the study indicate that household needs are associated with specific phases of the family cycle. The need for companionship rather than performance of domestic chores was accentuated by the aged rather than the newly married. Employers' age, income, type of marriage and length, ethnic and marital status are associated with the demand for domestic servants. Households engage domestic servants for the performance of domestic chores to reduce workload, and prevent isolation of the aged. We argue that households will continue to make demands for domestic servants as economic institutions and pursuits continue to dominate other non-economic institutions. It is unlikely to stop owing to the prevailing reduction of child fostering practices around Africa. It is, therefore, suggested that welfare programmes be developed by government to meet the needs of the aged and working women. Specifically, childcare facilities could be established in organisations while closing hours for women should be reduced to enable them attend to domestic roles. Abandoning the child in the hands of domestic servants has implications for the training and socialization of children, which mothers are qualified to inculcate. 
International Journal of Child, Youth and Family Studies (2012) 4.1: 521-545

\section{References}

Adamassie, A. (2003). Child labor and schooling in the context of a subsistence rural economy: Can they be compatible? International Journal of Educational Development, 23(2), 167-185.

Aderinto, A. A. (2000). Social correlates and coping measures of street children: A comparative study of street and non-street children in Southwestern Nigeria. Child Abuse \& Neglect, 24(9), 1199-1213.

Afolayan, A. A. (1994). Population. In M. O. Filani, F. O. Akintola, \& C.O. Ikporukpo (Eds.), Ibadan region (pp. 123-135). Ibadan: Rex Charles Publication, in association with Connel Publications.

Agbaje, A. (2002). Personal rule and regional policies: Ibadan under military regime, 19861996. In J. I. Guyer, L. Denzer, \& A. Agbaje (Eds.), Money struggles and city life: Devaluation in Ibadan and other urban centres in Southern Nigeria, 1986-1996 (pp. 3-26). Portsmouth, NH: Heinemann.

Altink, S. (1995). Stolen lives: Trading women into sex and slavery. London: Scarlet Press.

Ariyo, D. (2001). The future lost: The economic and social consequences of child abuse in Africa. Unite Against Abuse Newsletter. Retrieved from http://www.afbis.com/analysis/child_abuse.htm

Baxter, J. (1992). Power, attitude and time: The domestic division of labour. Journal of Comparative Family Studies 23(2), 165-182.

Bertone, A. M. (2000). Sexual trafficking in women: International political economy and the politics of sex. Gender Issues, 18(1), 4-22.

Bureau of International Labour Affairs. (1998). By the sweat and toil of children. Child Labour Series. Washington, DC: U.S Department of Labour.

Central Bank of Nigeria. (1996). Collaborative study on Nigeria's prospects for development. Proceedings of a Central Bank of Nigeria Workshop, April 15-17.

Coser, L. (1973). Servants: The obsolescence of an occupation role. Social Forces, 52(1), 3140.

Creswell, J. W. (1999). Mixed method research: Introduction and application. In T.Cijek (Ed.), Handbook of educational policy (pp. 455-472). San Diego: Academic Press.

Daly, K. J. (1996). Families and time: Keeping pace in hurried culture. Thousand Oaks, CA: Sage Publications.

Ehrenreich, B. (2000). Servico a la medida: Las politicas del trabajo de las otras mujeres. Debate Feminista: Intimidad Servicios, 22, 76-99. 
Epstein, C. F. (2004). Border crossings: The constraints of time norms in transgressions of gender and professional roles. In C. F. Epstein \& A. L. Kalleberg (Eds.), Fighting for time (pp. 317-340). New York: Russel Sage.

Ericksen, J. A., Yancey, W. L., \& Ericksen, E. P. (1979). The division of family roles. Journal of Marriage and the Family. 37(May), 301-313.

Erinosho, O. (2005). The burden of our women. The $29^{\text {th }}$ Interdisciplinary Research Discourse, Organized by the Postgraduate School, University of Ibadan.

Federal Republic of Nigeria. (2007). Official gazette (FGN). Lagos: Federal Government Press.

Gershuny, J., Godwin, M., \& Jones, S. (1994). The domestic labour revolution: A process of lagged adaptation. In M. Anderson, F. Bechhofer, \& S. Kendrick (Eds.), The social and political economy of the household (pp. 151-197). Oxford: Oxford University Press.

Glass, J., \& Camarigg, V. (1992). Gender, parenthood and family-work compatibility. American Journal of Sociology, 98(1), 131-151.

Greene, J. C., \& Caracelli, V. J. (Eds.). (1997). Advances in mixed-method evaluation: The challenges and benefits of integrating diverse paradigms (New Directions for Evaluation, No. 74). San Francisco: Jossey-Bass.

Guyer, J. I., Denzer, L., \& Agbaje, A. (2002). Introduction: The Nigerian popular economystrategies towards a study. In J. I. Guyer, L. Denzer, \& A. Agbaje (Eds.), Money struggles and city life: Devaluation in Ibadan and other urban centers in Southern Nigeria, 1986-1996 (pp. xvii-xlv). Portsmouth, NH: Heinemann.

Hakim, C. (1996). Key issues in women's work. London: Athlone

Hakim, C. (2000). Work-life choices in the $21^{\text {st }}$ century: Preference theory. Oxford: Oxford University Press.

Hakim, C. (2002). Lifestyle preferences as determinants of women's differentiated labour market careers. Work and Occupations, 29(4), 428-459. ISSN 0730-8884

Hochschild, A. R. (1997). The time bind: When work becomes home and home becomes work. New York: Metropolitan.

Hodges, A. (2001). Children and women's rights in Nigeria: A wake-up call. Situation and analysis. Abuja: National Planning Commission.

Hutton, W., \& Giddens, A. (Eds.). (2000). On the edge: Living with global capitalism. London: Jonathan Cape.

International Labour Organisation (ILO). (1994). Home work report. International Labour Conference 82nd Session. Geneva: Author. 
International Journal of Child, Youth and Family Studies (2012) 4.1: 521-545

International Labour Organisation (ILO). (2002). Forced labour, child labour and human trafficking in Europe: An ILO perspective. Paper presented at the European conference on preventing and combating human trafficking: Global challenges for the 21st century, September 18-20, Brussels, Belgium.

International Labour Organization (ILO). (2003, June 12). World day against child labour [Press release]. Retrieved from http://www.ilo.org/asia/info/public/pr/WCMS_182848/lang--en/index.htm

International Labour Organisation/International Programme on the Elimination of Child Labour (ILO/IPEC). (2001). Synthesis report on trafficking in children for labour in West Africa and Central Africa. Geneva: Author.

International Organization for Migration (IOM). (1995). Trafficking and prostitution: The growing exploitation of migrant women from central and eastern Europe. Migration Information Programme. Geneva: Author.

International Organization for Migration (IOM). (2005). Is trafficking in human beings demand driven? A multi-country pilot study (IOM migration research series No. 15). Geneva: Author.

Isamah, A., \& Okunola. R. A. (2003). Family life under economic adjustment: The rise of child breadwinners. In J. I. Guyer, L. Denzer, \& A. Agbaje (Eds.), Money struggles and city life: Devaluation in Ibadan and other urban centers in Southern Nigeria, 1986-1996 (pp. 63-72). Portsmouth, NH: Heinemann.

Isiugo-Abanihe, U. (1994). Parenthood in sub-Saharan Africa: Child fostering and its relationship with fertility. In T. Locoh \& V. Hertrich (Eds.), The onset of fertility transition in sub-Saharan Africa (pp. 163-174). Liège, Belgium: Derouaux Ordina Editions.

Isiugo-Abanihe, U. (2010). Continuity and change in Nigeria's fertility regime. An Inaugural Lecture delivered at the University of Ibadan, Nigeria.

James-Burdumy, S. (2005). The effect of maternal labour force participation on child development. Journal of Labour Economics, 23(1), 177-211.

Kamerman, S. B., Neumann, M., Waldvogel, J., \& Brooks-Gun, J. (2003). Social policies, family types and child outcomes in selected OECD countries (OECD social, employment and migration working papers, No. 6). Paris: OECD.

Kelly, L. (2005). "You can find anything you want”: A critical reflection on research on trafficking in persons within and into Europe [Special issue]. International Migration, 43(1/2), 235-265.

Laczko, F. (2005). Data and research on human trafficking [Special issue]. International Migration, 43(1/2), 5-16. 
International Journal of Child, Youth and Family Studies (2012) 4.1: 521-545

Lazaridis, G. (2001). Trafficking and prostitution: The growing exploitation of migrant women in Greece. The European Journal of Women's Studies, 8(1), 67-102.

Lutz, H. (2002). At your service madam! The globalization of domestic service. Feminist Review, 70(1), 89-104.

MacDermid, S. M. (2005). (Re)Considering conflict between work and family. In E. E. Kossek \& S. J. Lambert (Eds.), Work and life integration (pp. 19-40). Mahwah,NJ: Lawrence Erlbaum.

Martin, J., \& Roberts, C. (1984). Women and employment: A lifetime perspective. Report on the Department of Employment/OPCS Survey. London: Her Majesty’s Stationery Office.

McRae, S. (1993). Returning to work after childbirth: Opportunities and inequalities. European Sociological Review, 9(2), 125-138.

Merton, R. K. (1957). The role-set: Problems in sociological theory. The British Journal of Sociology, 8(2), 106-120.

Moen, P. (Ed.). (2003). It's about time: Couples and careers. Ithaca, NY: Cornell University Press.

Morrice, J. K. W., Taylor, R. C., Clark, D., \& McCann, K. (1985). Oil wives and intermittent husbands. British Journal of Psychiatry, 147(5), 479-483.

Okaba, B., \& Okolie, C. M. (2004). Political economy of human trafficking and child labour in Nigeria. In V. T. Jike (Ed.), The scourge of child labour in Nigeria: A book of readings (pp. 190-204). Lagos: NIS.

Okafor, E. E. (2009). The use of adolesecents as domestic servants in Ibadan, Nigeria. Journal of Adolescent Research, 24(2), 169-193.

Okafor, E. E., \& Amayo, E. O. (2006). Parents and their coping strategies in Nigeria: A study of selected working mothers. International Journal of Sociology of the Family, 32(1), 87-111.

Okafor, E. E., \& Bode-Okunade, A. S. (2003). Institutional collapse and child labour: The pervasive problem of street hawking in Nigeria. In V. T. Jike (Ed.), The scourge of child labour in Nigeria: A book of readings (pp. 90-102). Lagos: NIS.

Okereke, G. O. (2002). Incidence of physical spouse abuse in Nigeria: A pilot study. Research Reviews NS, 18(2), 39-51.

Olateru-Olagbegi, O. (1997). The social and legal implications on trafficking in women and children in Nigeria: The modern slavery.

Olutayo A. O. (1994). Systemic source of working children in Africa: The case of Nigeria. Childhood, 2(4), 207-211. 
International Journal of Child, Youth and Family Studies (2012) 4.1: 521-545

Onyeonoru, I. (2003). Push factors in girls' trafficking for international commercial sex work and the gender implications: A study of Benin, Edo State. African Journal of Peace and Conflict Studies, 1(1/2), 118-139.

Onyeonoru, I. P. (2005). Industrial sociology: An African perspective. Ibadan: Samlad Publishers.

Onyeonoru, I. P., \& Fayankinmu, A. E. (2001). Working mothers and breastfeeding: Issues in women’s occupation health. Nigerian Journal of Applied Psychology, 6(1), 133-142.

Olukoshi A. O., \& Aminu, L. S. (1990). The child in contemporary Nigeria: An introduction to the issue. In L. S. Aminu \& A. O. Olukoshi (Eds.), The Nigerian child now and in the future (pp. 143-151). Lagos: UNICEF/Federal Ministry of Health.

Otite, O., \& Ogionwo, W. O. (1979). An introduction to sociological studies. Ibadan: Heinemann Education Book Ltd.

Rigg, R. C., \& Cosgrove, M. P. (1994). Aircrew wives and the intermittent husband syndrome. Aviation, Space, and Environmental Medicine, 65(7), 654-660.

Scanzoni, J. (1978). Sex roles, women's work and marital conflict. Lexington, MA: Lexington Books.

Semenitari, I. (1998, June). Children of lesser grade. Tell Magazine, 10-11.

Stanley, L. (2002). "Shadows lying across her pages": Epistolary aspects of reading "The Eventful I” in the Olive Shreiner's letters. Journal of European Studies, 32, 251-266.

Somers, M., \& Gibson, G. (1994). Reclaiming the epistemological “other”: Narrative and social construction of identity. In C. Calhoun (Ed.), Social theory and the politics of identity (pp. 37-99). Oxford, UK: Basil Blackwell.

Tade, O. (2010). Household demand and child trafficking for domestic use in Oyo State, Nigeria. Ph.D. thesis, Department of Sociology, University of Ibadan.

Tade, O., \& Aderinto, A. A. (2011). Socio-demographic predictors of outsourcing among working women in Ibadan, Nigeria. Pakistan Journal of Social Sciences, 8(4) 198204.

United States Department of State. (1999). Country reports on human rights practices for 1998. Washington, DC: Bureau of International Labour Affairs.

United States Department of State. (2009, June). Trafficking in persons report. Washington, DC: Author.

United Nations Educational and Scientific Organization (UNESCO). (2006). Human trafficking in Nigeria: Root causes and recommendations. Policy Paper Poverty Series No. 14.2 (E). New York: Author. 
International Journal of Child, Youth and Family Studies (2012) 4.1: 521-545

United Nations International Children's Education Fund (UNICEF). (1997). The state of the world's children. Oxford, UK: Oxford University Press.

United Nations International Children’s Education Fund (UNICEF). (2004). Child labour. Abuja, Nigeria: Author.

United Nations International Children's Education Fund (UNICEF). (2006). The state of the world's children, 2006: Excluded and invisible. New York: UNICEF.

Van der Lippe, T. (2007). Dutch workers and time pressure: Household and workplace characteristics. Work, Employment and Society, 21(4), 693-711.

Voydanoff, P., \& Kelly, R. F. (1984). Determinants of family-related work problems among employed parents. Journal of Marriage and Family, 46(4), 881-892.

Wusu, O., \& Isiugo-Abanihe, U. C. (2003). Family structure and reproductive health decision-making among the Ogu of southwestern Nigeria: A qualitative study. African Population Studies, 18(2), 27-45. 